\title{
Kebijakan Respons Indonesia terhadap Problematika Teroris-Kombatan Transnasional Pasca Bom Bali 2002 Indonesia's Policy Response to Foreign Terrorist Fighter Problem In Post-2002 Bali Bombings
}

\author{
Ali Abdullah Wibisono \\ Departemen Hubungan Internasional, Universitas Indonesia \\ email: ali.abdullah61@ui.ac.id
}

\begin{tabular}{l}
\hline Riwayat Artikel \\
\hline Diterima: 29 Oktober 2019 \\
Direvisi: 9 Maret 2020 \\
Disetujui: 21 April 2020 \\
doi: $10.22212 /$ jp.v11i1.1543
\end{tabular}

\section{Abstract}

Indonesia's response to the problem of foreign terrorist fighters has changed from time to time. From the New Order era until the beginning of the reform period, tolerant attitude was applied. However, in the reform era, Indonesia's response changed from a humanitarian-based to prudence-based attitude. This article applies the theoretical mapping of counter-terrorism by David Crelinsten and explains that this change is not only due to perceptions of the potential threat of combatants returming to their homeland, but also the readiness of social reintegration and de-radicalization programs, adherence to international regimes, and domestic political processes. In addition to getting data on the dynamics and number of Indonesian combatants from mass media and journal articles, this article also processes data derived from proceedings of the revision of the anti-terrorism law passed in 2018. Indonesia's attitude towards the current problem of transnational terrorist- combatants is high selectivity, not total rejection or revocation of citizenship. Successful social reintegration for former combatants -- domestic and transnational -remains a challenge to be addressed ahead.

Keywords: Foreign Terrorist Fighter; Counter-Terrorism; International Regimes; Domestic Politics.

Abstrak
ResponsIndonesiaterhadapproblematikateroris-kombatantransnasionalmengalami
perubahan dari masa ke masa. Di era order baru hingga awal masa reformasi, sikap
toleran diterapkan. Sementara itu, di era reformasi respons Indonesia berubah dari
sikap humaniter menjadi kehati-hatian. Artikel ini menerapkan pemetaan teoretik
kontra-terorisme dari David Crelinsten dan menjelaskan bahwa perubahan ini tak
hanya diakibatkan persepsi terhadap potensi ancaman kombatan yang kembali ke
tanah air, tapi juga kesiapan program reintegrasi sosial dan deradikalisasi, kepatuhan
kepada rezim internasional, dan proses politik domestik. Selain mendapatkan
data tentang dinamika dan jumlah kombatan Indonesia dari media massa dan
artikel-artikel jurnal, artikel ini juga mengolah data yang berasal dari prosiding
revisi undang-undang anti-terorisme yang disahkan tahun 2018. Sikap Indonesia
terhadap problematika teroris-kombatan transnasional saat ini adalah selektivitas
tinggi, bukan penolakan total atau pencabutan kewarganegaraan. Kurangnya
kemampuan untuk melakukan reintegrasi sosial bagi mantan kombatan, domestik
maupun transnasional, menandai pekerjaan rumah yang masih tersisa. Penolakan
pemerintah untuk memfasilitasi repatriasi tidak berarti penolakan total terhadap
kepulangan semua teroris-kombatan transnasional, sehingga kepulangan individual
dengan fasilitasi mandiri masih dimungkinkan. Penolakan ini merefleksikan
keterbatasan kemampuan pemerintah dan masyarakat untuk merehabilitasi
dan mereintegrasikan para teroris-kombatan, ketimbang reaksi terhadap potensi
ancaman teroris-kombatan transnasional.
Kata kunci: Teroris Kombatan Transnasional; Kontra-Terorisme; Rezim
Internasional; Politik Domestik.




\section{Pendahuluan}

Pada 25 Mei 2018, Indonesia untuk pertama kalinya memiliki instrumen legalformal untuk merespons problematika foreign terrorist fighter atau teroris-kombatan transnasional (selanjutnya disebut TKT), yaitu Undang-Undang Nomor 5 tahun 2018 tentang Perubahan Atas Undang-Undang Nomor 15 tahun 2003 tentang Penetapan Penetapan Peraturan Pemerintah Pengganti Undang-Undang Nomor 1 Tahun 2002 Tentang Pemberantasan Tindak Pidana Terorisme Menjadi Undang-Undang (selanjutnya disebut "UU No.5/2018" atau "Revisi Undang-Undang Anti-Terorisme"). Pasal 12 B dari undang-undang ini, antara lain, memidanakan penyelenggaraan, pemberian, partisipasi dalam pelatihan militer atau paramiliter di dalam dan luar negeri dengan tujuan merencanakan, mempersiapkan atau melakukan aksi terorisme. ${ }^{1}$ Pada tanggal 11 Februari 2020, pemerintah mengumumkan hasil rapat terbatas yang dipimpin Presiden Joko Widodo untuk "menolak memulangkan teroris lintas batas" atas nama "pemenuhan rasa aman masyarakat" dan membentuk tim verifikasi yang akan mengumpulkan data yang lebih valid tentang para WNI yang bergabung dengan NIIS. ${ }^{2}$ Keputusan ini mendapat dukungan luas masyarakat, tetapi meninggalkan catatan politik untuk mencegah memburuknya ketidakpercayaan masyarakat kepada lembaga publik yang disinyalir sebagai akar masalah problematika kombatan transnasional. $^{3}$

1 Republik Indonesia, "Undang-Undang No. 5/2018 Tentang Perubahan Atas Undang-Undang No.15/2003 Tentang Penetapan PERPU No.1/2002 Menjadi Undang-Undang." (2018).

2 "Pemerintah Tak Memulangkan", KOMPAS, Rabu 12 Februari 2020

3 J. Kristiadi, "Analisis Politik: Pasca Penolakan Pemulangan Kombatan NIIS”, KOMPAS, Kamis 20 Februari 2020
Sikap penolakan pemulangan returnis bertolak belakang dengan sikap pemerintah tahun 2017. Badan Nasional Penanggulangan Terorisme (BNPT), bersama Kementerian Sosial dan organisasi non-pemerintah, dengan Kementerian Sosial sebagai focal point mengupayakan pembinaan kepada 226 deportan dan returnis yang terindikasi berasosiasi dengan organisasi Negara Islam di Irak dan Suriah (NIIS). ${ }^{4}$ Kementerian Sosial juga menekankan pada penanganan penyembuhan trauma dan konseling untuk anak-anak dan perempuan yang mendominasi jumlah mereka yang dideportasi pemerintah Turki karena akan bergabung dengan kepala keluarga mereka yang telah lebih dahulu ke Suriah. ${ }^{5} \mathrm{Di}$ antara para deportan ada pula pekerja migran Indonesia yang dideportasi karena terindikasi mengalami radikalisasi selama di negara tempat bekerja. ${ }^{6}$

Bagaimana memaknai perubahan sikap pemerintah Indonesia terhadap problematika teroris-kombatan transnasional? Argumen utama dari artikel ini adalah respons Indonesia terhadap problematika teroriskombatan transnasional tidak sematamata dibentuk oleh ancaman potensial dari returnis kombatan dan non-kombatan dari organisasi NIIS. Respons negara terhadap teroris-kombatan transnasional (TKT) dipengaruhi oleh empat faktor. Pertama, adalah kemampuan negara untuk menyelenggarakan program reintegrasi

4 BNPT \& Kementerian Sosial. Presentasi Data Deportan dan Returnis yang Ditangani Kementerian Sosial dan BNPT. Jakarta: Kementerian Sosial dan BNPT, 2017.

5 BNPT. "Shelter Kemensos Rehabilitasi 129 WNI Terkait Terorisme", 25 Maret 2017, diakses 25 Maret 2017, https://www.bnpt.go.id/shelterkemensos-rehabilitasi-129-wni-terkait-terorisme. html

6 The Habibie Center, "Countering Vulnerability to Human Trafficking in Violent Extremism in Southeast Asia: A Case of Indonesia," 2018. 
sosial mantan kombatan. Indonesia belum memiliki kapasitas deradikalisasi dan reintegrasi mantan kombatan yang efektif sebagaimana ditunjukkan oleh keberlanjutan dan pembaruan jaringanjaringan terorisme setelah penangkapan dan pemenjaraan pelaku terorisme.

Kedua, kepatuhan Indonesia terhadap rezim atau konvensi-konvensi tertentu yang mengatur status kombatan asing yang mendorong negara-negara bertindak selektif atau menolak kembalinya returnis kombatan asing. Rezim internasional yang dibentuk Dewan Keamanan PBB memaksa Indonesia untuk bersikap lebih selektif terhadap returnis kombatan transnasional dan menciptakan mekanisme hukum yang menghalangi keberangkatan kombatan.

Ketiga, perubahan pola gerakan terorisme yang mengikutsertakan orangorang yang berada di luar jaringan terorisme. Mereka yang sebelumnya belum pernah menjadi bagian dari jaringan terorisme menjadi bagian dari kombatan yang bergabung dengan NIIS. Sementara itu, kemunculan NIIS secara langsung mengakibatkan perubahan peta pergerakan terorisme di Indonesia. Hal ini mendorong Indonesia untuk membangun identifikasi profil WNI yang bergabung dengan NIIS dan secara lebih proaktif memutus mata rantai jaringan terorisme transnasional.

Keempat adalah faktor politik domestik yang mempertimbangkan kebahayaan dan respons yang layak bagi returnis organisasi teroris asing. Proses politik domestik yang menjadikan proses hukum bagi para returnis untuk membuktikan keterlibatan mereka sebagai prioritas akan menghindari penolakan total terhadap para returnis.

Artikel ini terdiri dari lima bagian. Bagian kedua yang mengikuti pendahuluan ini adalah tinjauan pustaka yang diarahkan untuk memetakan pembahasan literatur- literatur yang ada tentang faktor-faktor yang membentuk respons negara terhadap problematika TKT. Bagian ketiga menjelaskan sejarah problematika TKT di Indonesia yang menunjukkan bahwa problematika ini adalah bagian integral dari persoalan terorisme, berkontribusi penting terhadap peningkatan kebahayaan terorisme. Bagian ke-empat menjelaskan respons Indonesia terhadap problematika TKT, yang terdiri dari perincian dari bentuk-bentuk tindakan yang digariskan UU Nomor 15 tahun 2003 Tentang Penetapan Peraturan Pemerintah Pengganti Undang-Undang Nomor 1 Tahun 2002 Tentang Pemberantasan Tindak Pidana Terorisme Menjadi Undang-Undang (selanjutnya disebut "UU Anti-Terorisme" atau "UU No.15/2003"), UU No. 5/2018, dan peraturan-peraturan lain, dan proses perdebatan di DPR-RI berkenaan dengan substansi pengaturan yang relevan dengan persoalan TKT dalam UU No.5/2018. Bagian kelima adalah kesimpulan tentang faktor-faktor yang membentuk respons negara terhadap TKT dan saran-saran untuk peningkatan efektivitas respons.

\section{Permasalahan}

Pertanyaan utama yang dibahas artikel iniadalah faktor-faktor apa yang membentuk respons negara terhadap problematika TKT. Dengan membahas pertanyaan ini, artikel ini bertujuan memetakan kebijakan-kebijakan anti-terorisme Indonesia yang relevan bagi problematika TKT sekaligus memberikan rekomendasi bagi komponen-komponen kebijakan yang belum terpenuhi. Selain itu, artikel ini juga bertujuan menyajikan hasilhasil pembahasan studi terorisme berkenaan respons negara terhadap TKT, termasuk apa saja bentuk respons tersebut dan apa yang mempengaruhinya. 
Kerangka Pemikiran Respons negara terhadap Returnis Kombatan-Teroris Transnasional

\section{Definisi Konseptual}

Definisi kombatan transnasional (foreign fighter) telah dirumuskan oleh penulispenulis sebelumnya. Bakker dan de Bont misalnya, mendefinisikan 'jihadist foreign fighter' atau kombatan jihadis transnasional sebagai individu-individu warga negara tertentu yang telah bergabung dengan kelompok bersenjata di suatu konflik luar negeri dengan agenda jihadisme. ${ }^{7}$ Sementara itu definisi lain yang lebih dapat diterima secara luas mengatakan bahwa foreign fighters (kombatan transnasional) adalah individu-individu yang melakukan perjalanan ke negara lain dengan tujuan membantu memerangi pasukan asing yang melakukan pendudukan (occupying forces) atau rezim yang korup. ${ }^{8}$ Dengan melihat definisi-definisi ini, komponen-komponen yang penting dari kombatan transnasional adalah ketidaksamaan kewarganegaraan, ras, dan etnis; karakter non-profit; keadaan telah bergabung dengan suatu kelompok bersenjata (bukan sebagai non-kombatan); dan tujuan politik atau ideologis. Sehingga dalam artikel ini kombatan transnasional adalah individu yang telah bergabung dengan kelompok bersenjata di suatu konflik di luar negaranya karena individu tersebut mendukung apa yang diperjuangkan oleh kelompok bersenjata tersebut, bukan

7 Edwin Bakker \& Roel de Bont, "Belgian and Dutch Jihadist Foreign Fighters (2012-2015): Characteristics, Motivations, and Roles in the War in Syria and Iraq," Small Wars and Insurgencies 27, no. 5 (2016): 837-57, https://doi.org/10.1080/0959 2318.2016.1209806.

8 R. Kim Cragin \& Susan Stipanovich, "Metastases: Exploring the Impact of Foreign Fighters in Conflicts Abroad," Journal of Strategic Studies 42, no. 3-4 (2019): 395-424, https://doi.org/10.1080/0140 2390.2017 .1402766 . karena adanya persamaan etnis, ras dan kewarganegaraan, dan bukan pula karena insentif material. Imbuhan kata 'teroris' dalam teroris-kombatan transnasional (foreign terrorist fighter) menunjukkan bahwa individu tertentu tak hanya bepergian ke luar negeri dan bertempur bersama suatu kelompok bersenjata, tetapi bahwa kelompok tersebut telah dikategorikan sebagai kelompok terorisme oleh suatu pemerintahan berdaulat atau organisasi internasional beranggotakan negara-negara berdaulat seperti Perserikatan BangsaBangsa (PBB).

Kajian literatur tentang TKT belum secara eksplisit menjelaskan faktor-faktor yang membentuk respons negara terhadap mereka. Tetapi dari literatur-literatur yang ada, terdapat tiga kategori faktor yang mempengaruhi respons negara terhadap TKT, yaitu kebahayaan yang mereka tunjukkan, rezim internasional yang mengatur keberadaan mereka dan proses domestik penetapan prioritas kebijakan politik-keamanan. Kategori pertama dari pembahasan respons negara terhadap TKT adalah analisis terhadap kadar kebahayaan kombatan transnasional. Sejumlah penulis sepakat dalam menunjuk kepada TKT sebagai faktor yang mengamplifikasi konflik bersenjata di negara lain, dan mengakibatkan peningkatan ekstremisme di negara asal TKT. ${ }^{9}$ Tetapi lebih dari itu, kebahayaan TKT tidak hanya muncul sekembalinya mereka dari "tanah pertempuran", melainkan sejak mereka masih ada di sana. Individu-individu TKT dapat melakukan "directed-attack" atau serangan yang diinstruksikan dari tempat mereka menjadi

9 Daniel Byman, "The Homecomings: What Happens When Arab Foreign Fighters in Iraq and Syria Return?," Studies in Conflict and Terrorism 38, no. 8 (2015): 581-602, https://doi.org/10.1080/105761 OX.2015.1031556. 
kombatan di negara asalnya. ${ }^{10}$ Sementara itu mereka yang kembali sebagai returnis ke negara asalnya pun boleh jadi membawa "instruksi" untuk melakukan serangan, propaganda dan rekrutmen untuk mengirim lebih banyak kombatan dan keluarganya. ${ }^{11}$

Namun beberapa penulis memiliki pendapat yang berbeda tentang kebahayaan returnis TKT atau individu-individu yang pernah bergabung dengan organisasi teroris transnasional lalu kembali ke negara asalnya. Salah satu hasil penelitian menemukan bahwa returnis TKT yang bergabung dengan jaringan atau sel terorisme domestik akan mengakibatkan aksi serangan sel tersebut lebih mudah didisrupsi penindakan pemerintah. ${ }^{12}$ Catatan terhadap kebahayaan TKT juga ditulis David Mallet yang memperkirakan kapan sejak kepulangan mereka ke tanah air, TKT menjadi suatu ancaman. Ia memandang bahwa jeda waktu (lag time) dari kepulangan TKT ke negara asalnya hingga mereka melakukan aksi penyerangan adalah masa krusial bagi aparat keamanan negara untuk melakukan tindakan preventif terhadap returnis TKT. ${ }^{13}$ Penelitian Mallet mengenai selisih waktu antara waktu kembalinya TKT dengan aksi teror yang mereka lakukan, menganjurkan perlunya tindakan preventif yang segera terhadap returnis TKT. Berdasarkan data

10 David Malet \& Rachel Hayes, "Foreign Fighter Returnees: An Indefinite Threat?," Terrorism and Political Violence 00, no. 00 (2018): 1-19, https:// doi.org/10.1080/09546553.2018.1497987.

11 Oldrich Bures, "EU's Response to Foreign Fighters: New Threat, Old Challenges?," Terrorism and Political Violence 00, no. 00 (2018): 1-18, https:// doi.org/10.1080/09546553.2017.1404456.

12 Christopher J. Wright, "Sometimes They Come Back: Responding to American Foreign Fighter Returnees and Other Elusive Threats," Behavioral Sciences of Terrorism and Political Aggression 0, no. O (2018): 1-16, https://doi.org/10.1080/19434472.2 018.1464493.

13 Malet \& Hayes, "Foreign Fighter Returnees: An Indefinite Threat?"
Lags in Attack Times of Extrimist Returnees (LATER) periode tahun 1980 - 2016, dari 230 orang yang baru kembali ke negara asalnya (Uni Eropa, Amerika Serikat dan Australia) sebagai returnis TKT, sebagian besar melakukan aksi di 1 tahun pertama kepulangannya, rata-rata melakukannya di 4 bulan pertama. Oleh karena itu, Mallet merekomendasikan respons yang dapat dilakukan oleh negara untuk mencegah returnis TKT melakukan aksi di negaranya harus dilakukan di 6 bulan pertama kepulangannya. Penelitian-penelitian ini tidak menyangkal potensi kebahayaan returnis TKT bagi negara asalnya, tetapi memberikan kualifikasi penting: bahwa negara-negara yang siap dengan perangkat surveillance dan mekanisme re-integrasi sosial akan lebih mampu merespons kebahayaan TKT, dan respons ini perlu dilakukan dengan segera, tepatnya dalam periode 6 bulan sejak kepulangan mereka.

Penelitian lain mempertimbangkan potensi kebahayaan suatu negara menjadi "produsen" TKT dengan melihat kondisi sosial ekonomi dan politik negara-negara asal TKT. Berdasarkan kajian yang dilakukan oleh Benmelech, ${ }^{14}$ orang-orang yang menjadi TKT dalam Islamic States of Iraq and Syria (ISIS) berasal dari negara-negara yang secara kondisi ekonomi memiliki pendapatan per kapita tinggi dan memiliki kondisi politik yang stabil. Seperti halnya data yang dikemukakan oleh Bures ${ }^{15}$ yang menyebutkan bahwa 3000-5000 TKT aktif di Suriah dan Irak berasal dari negara - negara anggota Uni Eropa yang secara ekonomi dan politik lebih maju. Orang-orang yang menjadi TKT cenderung memiliki motif ideologis

14 Efraim Benmelech \& Esteban F. Klor, "What Explains the Flow of Foreign Fighters to ISIS?," Terrorism and Political Violence 00, no. 00 (2018): 1-24, https://doi.org/10.2139/ssrn.2777466.

15 Bures, "EU's Response to Foreign Fighters: New Threat, Old Challenges?" 
dan ketidakmampuan melakukan asimilasi dengan masyarakat di negara-negara Barat. ${ }^{16}$

Kategori kedua dari pembahasan tentang respons negara terhadap para returnis kombatan transnasional berkenaan dengan kepentingan politik negara-negara di dunia yang tidak sama yang mengakibatkan variasi dalam respons negara-negara terhadap TKT. Menurut Byman, negara bahkan dapat melakukan eksploitasi atau pemanfaatan kombatan transnasional. Mereka dimanfaatkan untuk membantu menumbangkan rezim yang berkuasa, contohnya Turki memasok bantuan logistik ke kombatan transnasional untuk membantu kelompok sunni menggoyahkan rezim Assad. Sebaliknya, Iraq mengirim kombatan transnasional untuk mendukung rezim Assad mengatasi pemberontakan. Kedua, negara melakukan pembiaran mobilisasi kombatan transnasional dari negaranya ke negara lain agar dapat menghilangkan kelompok radikal di negaranya. Contohnya pemerintah Yaman membiarkan warganya untuk pergi ke Iraq selama mereka tidak membuat kekacauan di dalam negeri. Selain itu, tindakan pembiaran ini juga dipengaruhi oleh kalkulasi politik domestik, misalnya ketika aktor politik yang berpengaruh di suatu negara memiliki keterkaitan/afiliasi dengan kombatan transnasional, maka pemerintah membiarkan mereka agar tidak menimbulkan instabilitas politik domestik. Ketiga, ketidakmampuan (incapacity) negara menjaga batas-batas wilayahnya. Misalnya Somalia yang memiliki pemerintahan yang lemah sehingga tidak memiliki cukup control untuk menjaga wilayah perbatasannya dari mobilitas foreign fighter. Byman mengatakan bahwa upaya mencegah kombatan transnasional tidak akan cukup tanpa adanya politicall will dari

16 Benmelech \& Klor, "What Explains the Flow of Foreign Fighters to ISIS?" negara-negara di dunia. ${ }^{17}$ Temuan Byman ini menganjurkan pentingnya respons komunitas Internasional terhadap TKT. Dalam hal ini komunitas Internasional penting untuk membentuk hukum yang tidak mentolerir fenomena TKT dan diterapkan secara bersama-sama. Byman menjelaskan bahwa fenomena TKT justru dimanfaatkan oleh negara untuk menggulingkan rezim di negara lain ataupun oposisi pemerintah. Hal ini dilakukan negara dengan cara mentoleransi aktivitas dari TKT, bahkan mendanai kebutuhannya dengan tujuan untuk menjaga kestabilan dalam negeri.

Pada kategori literatur ketiga, konsensus institusional juga merupakan pertimbangan penting dalam menentukan kebijakan bersama terhadap TKT, khususnya di level regional. Bures meneliti ragam tindakan yang dilakukan Uni Eropa terhadap TKT, di antaranya penguatan peraturan perbatasan, kriminalisasi perjalanan ke wilayah konflik untuk kegiatan terorisme, penerapan EU Passenger Name Record yang mewajibkan maskapai udara untuk menyerahkan data penumpang pesawatpesawat yang berasal dari negara luar Uni Eropa dan pertukaran informasi yang lebih baik dari Europol dan Eurojust. ${ }^{18}$ Bures juga mengungkapkan perbedaan persepsi antara negara-negara anggota Uni Eropa mengenai respons terhadap TKT. Rekomendasinya adalah bahwa kebijakan TKT di negara-negara demokrasi membutuhkan keseimbangan antara efektifitas dalam mencegah serangan terror dan akuntabilitas untuk mencegah terkikisnya kebebasan sipil. $^{19}$

17 Daniel Byman, "How States Exploit Jihadist Foreign Fighters," Studies in Conflict and Terrorism 0, no. 0 (2017): 1-15, https://doi.org/10.1080/1057610X.2017.1361281.

18 Bures, "EU's Response to Foreign Fighters: New Threat, Old Challenges?"

19 Javier Argomaniz, Oldrich Bures, \& Christian Kaunert, "A Decade of EU Counter-Terrorism and Intelligence: A Critical Assessment," Intelligence and National Security 30, no. 2-3 (2015): 191-206, https://doi.org/10.1080/02684527.2014.988445. 
Simpulan yang dapat diambil dari berbagai kajian terdahulu adalah saat suatu negara mampu mengidentifikasi karakteristik TKT dan menentukan tingkat kebahayaan dari kemunculan mereka, hal itu memberikan keuntungan tersendiri bagi mereka. Negara yang dapat melakukan tindakan antisipatif atau preventif terhadap kehadiran TKT, akan lebih efektif dalam mencegah kebahayaan TKT. Respons terhadap TKT tidak hanya dilakukan oleh negara tetapi juga oleh organisasi internasional seperti PBB dan entitas regional seperti Uni Eropa yang secara historis memiliki kebijakan kontraterorisme yang diterapkan terhadap negara - negara anggota. ${ }^{20}$

\section{Kerangka Pemikiran: Faktor- Faktor Pembentuk Respons Negara Terhadap Returnis Teroris-Kombatan Transnasional}

Melihat ragam literatur yang telah dibahas, belum ada artikel yang secara khusus membahas faktor-faktor yang mempengaruhi respons negara terhadap returnis kombatan asing, tetapi dari literatur yang ada dapat disimpulkan beberapa faktor yang dapat diderivasikan dari literaturliteratur tersebut.

Faktor pertama yang membentuk respons negara terhadap returnis kombatan asing adalah kemampuan kontraterorisme mereka. Kontra-terorisme adalah keseluruhan respons negara - pemerintah maupun masyarakat - terhadap terorisme, meliputi pembentukan sistem pemidanaan, instrumen koersif untuk penegakan hukum maupun tempur, kemampuan dan sistem intelijen, komunikasi publik, disrupsi

20 UNSC Counter-Terrorism Committee Executive DIrectorate (CTED), "The Challenge of Returning and Relocating Foreign Terrorist Fighters: Research Perspectives," n.d., 1-20. serangan terorisme, mitigasi korban akibat serangan, hingga respons jangka panjang terhadap akar masalah. ${ }^{21}$

Kesiapan kontra-terorisme diukur dari kemampuan negara untuk mengkonsolidasikan politik dalam negeri dalam merespons kebahayaan potensial yang muncul dari kombatan transnasional atau organisasi terorisme tertentu; kemampuan ini berkorelasi dengan kemauan negara untuk memobilisasi sumber daya yang diperlukan untuk: 1) memfasilitasi rehabilitasi dan reintegrasi pada returnis; 2) mengidentifikasi ragam profil returnis potensial yang harus diidentifikasi sebelum mereka dapat kembali masuk ke negaranya. Sumber daya besar dibutuhkan untuk melakukan penilaian risiko mengingat beragamnya bentuk keterlibatan warga dalam perang luar negeri, sehingga diperlukan bukti keterlibatan dan tingkat kebahayaan. Kemampuan identifikasi profil dan reintegrasi sosial adalah kemampuan yang kritis dibutuhkan dalam merespons terorisme, karena dalam jangka panjang efektivitas kontra-terorisme diukur dari jumlah mantan pelaku tindak pidana terorisme yang menganggap ideologi dan metode gerakan yang diusung jaringan terorisme sudah tidak relevan. ${ }^{22}$

Faktor kedua adalah rezim dan politik internasional yang berlaku berkenaan dengan kombatan asing. Karakter operasi organisasi terorisme yang menjadi target, termasuk infrastruktur sistemik yang memfasilitasi kerjanya; semakin mahir suatu organisasi terorisme memanfaatkan

21 R.D. Crelinsten, "Analysing Terrorism and CounterTerrorism: A Communication Model," Terrorism and Political Violence 14, no. 2 (2002): 77-122.

22 T. W. van Dongen, "Break It down: An Alternative Approach to Measuring Effectiveness in Counterterrorism," Journal of Applied Security Research 6, no. 3 (2011): 357-71, https://doi.org/10. 1080/19361610.2011.580264. 
jaringan atau koneksi yang ia miliki untuk melakukan aksi terorisme, semakin besar kebahayaan yang dipertimbangkan negara;

Faktor ketiga adalah proses politik domestik yang memutuskan kebijakan negara dalam merespons kombatan-teroris transnasional. Jika negara sudah menjadi bagian dari suatu konvensi atau rezim internasional yang mengkriminalkan foreign fighters dari organisasi atau konflik tertentu maupun secara umum, akan semakin sulit negara itu menerima kembali para returnis. Termasuk dalam pertimbangan ini adalah apakah ada asosiasi antara isu kombatan transnasional dengan kewarganegaraan dalam diskursus publik. Asosiasi antara status kewarganegaraan dan status kombatan transnasional akan mempersulit repatriasi kombatan ke negara asalnya, dan meningkatkan risiko mereka menjadi ancaman terorisme internasional. ${ }^{23}$

\section{Metode}

Data-data berkenaan dengan angka returnis konflik luar negeri dalam artikel ini didapatkan dari artikel-artikel jurnal internasional dan wawancara dengan narasumber dari Detasemen Khusus 88. Data tentang kebijakan pemerintah didapatkan dari artikel harian berita dan pencarian daring terhadap hukum-hukum yang relevan dalam penanggulangan terorisme.

Bentuk data lain yang juga relevan bagi penelitian ini adalah prosiding Rapat Dengar Pendapat Panitia Khusus Revisi Undang-Undang No.15/2003. Prosiding ini memberikan data penting tentang sikap fraksi-fraksi tentang setiap pasal dan ayat yang direvisi dan rasionalisasi apa yang

23 Adam K. Webb, “'Swanning Back in'? Foreign Fighters and the Long Arm of the State," Citizenship Studies 21, no. 3 (2017): 291-308, https://doi.org/10 $.1080 / 13621025.2016 .1252715$. diajukan, sehingga memberikan penjelasan tentang proses politik domestik yang menghasilkan sikap tertentu dari pemerintah dalam menyikapi returnis kombatan-teroris transnasional dan keluarga mereka.

\section{Respons PemerintahIndonesia Terhadap Kombatan-Teroris Transnasional}

Respons pemerintah terhadap fenomena teroris-kombatan transnasional bergerak dari pembiaran di era Orde Baru menjadi kriminalisasi di era pasca kebangkitan NIIS. Bagian ini menjelaskan perubahan masalah TKT Indonesia dan bagaimana respons pemerintah terhadapnya.

\section{Perkembangan Kemampuan Merespons Terorisme}

Kebijakan formal merespons terorisme belum ada sebelum tragedi Bom Bali tahun 2002. Pada masa tersebut, kebijakan merespons fenomena-fenomena yang diinklusi dalam literatur kajian terorisme Indonesia, umumnya melibatkan militer atau komunitas intelijen. Respons yang diberikan pemerintah tercermin dalam operasi-operasi militer berbentuk kontrainsurjensi dalam merespons Darul Islam/ Tentara Islam Indonesia pada 1959-1962, respons intelijen-militer terhadap Komando Jihad pada 1971-1981, respons militer terhadap beberapa kemunculan sporadic terorisme yang mengatasnamakan Islam di tahun 1980an. Meskipun mengendepankan militer, respons Indonesia menggunakan sistem peradilan untuk memberikan vonis hukum yang menggunakan UU AntiSubversi sebagai instrument pemidanaan.

Respons yang sangat represif ini efektif dalam menimbulkan penggentaran tetapi tak efektif dalam mencegah terbangunnya koneksi transnasional yang justru dimotivasi oleh represi tersebut. Koneksi transnasional ini mengikuti eksodus Abu Bakar Ba'ashir 
dan Abdullah Sungkar, dua ideolog proto salafy-jihad di Indonesia era akhir 1970-an dan 1980-an ke Malaysia, yang menghindari proses hukum pemerintah Orde Baru yang berusaha menindak mereka dengan pasal Anti-Subversi. Sejak 1980an, dengan meningkatnya eskalasi konflik di Afghanistan antara pejuang mujahidin dengan Uni Soviet, Sungkar dan Ba'asyir memfasilitasi seleksi dan pengiriman militan Indonesia untuk berpartisipasi dalam pelatihan jihadis di Afghanistan. ${ }^{24}$ Gelombang pertama adalah pada periode 1985-1992. Setidaknya 192 warga negara Indonesia yang terbagi dalam sepuluh Angkatan berpartisipasi dalam akademi militer Mujahidin Afghanistan.

Gelombang kedua terjadi sejak tahun 1994, ketika Filipina Selatan menjadi teater konflik yang atraktif dalam menarik eksodus militan Indonesia. Setidaknya ada 144 warga negara Indonesia yang terbagi dalam 12 angkatan yang mengikuti pelatihan di tempat pelatihan para militer di Filipina Selatan. Nasir Abbas dan rekanrekannya di Jemaah Islamiyah mendirikan Camp Hudaibiyah yang diserahkan sepenuhnya oleh Moro Islamic Liberation Front kepada Jemaah Islamiyah. ${ }^{25}$ Program pelatihan Camp Hudaibiyah selanjutnya menghasilkan lulusan-lulusan TKT paling mematikan bagi Indonesia di era reformasi, yaitu Noordin M. Top, Azahari Husein, dan Ali Fauzi; instruktur mereka adalah veteran TKT Afghanistan yang berangkat tahun 1990 bernama Fathurrahman Al Ghozi.

24 Mirra Noor Milla \& Djamaludin Ancok, "The Impact of Leader-Follower Interactions on the Radicalization of Terrorists: A Case Study of the Bali Bombers," Asian Journal of Social Psychology 16, no. 2 (June 3, 2013): 92-100, doi:10.1111/ ajsp.12007.

25 Solahudin \& Dave McRae, The Roots of Terrorism in Indonesia: From Darul Islam to Jema'ah Islamiyah (Sydney: NewSouth Publishing, 2011).
Pemerintahan Orde Baru tidak melakukan tindakan pengejaran atau penindakan apa pun terhadap individuindividu yang berangkat menuju Afghanistan dan Filipina Selatan. Keberangkatan mereka memang diseleksi dan difasilitiasi oleh Jemaah Islamiyah di Malaysia, sehingga penindakan keimigrasian seperti invalidasi paspor atau pencekalan tidak bisa dilakukan. Di sisi lain, pembiaran ini bersifat strategis untuk mengikis jumlah militan di Indonesia sementara di saat yang sama pemerintah memberikan ruang gerak yang lebih luas bagi dakwah Islam dan ekspresi moderat di era 1990an.

Di era reformasi, penguatan politik kelompok Islam membuat formulasi respons kebijakan yang jelas untuk mengantisipasi returnis TKT tidak menjadi prioritas. Sejumlah peraturan perundang-undangan yang dirancang di era reformasi sebenarnya telah berusaha untuk secara tidak langsung merespons dimensi transnasional dari problematika terorisme. Respons negara untuk mengatasi dimensi transnasional dari terorisme dapat dikategorikan setidaknya pada sektor masalah keorganisasian dan keanggotaan entitas/ korporasi terorisme dan aktivitas terorisme WNI di luar negeri.

Akibatnya, awal dari periode reformasi ditandai serangan-serangan terorisme yang difasilitasi oleh para returnis TKT Indonesia dari Afghanistan, Filipina maupun konflik lokal di Poso dan Ambon. Aksi-aksi yang melibatkan alumni Afghanistan mulai terlihat pada aksi pemboman di rumah kediaman Dubes Filipina pada 1 Agustus 2000 dan pemboman di malam Natal pada 24 Desember 2000, bom Plaza Atrium Senen tahun 2001, bom Bali I tahun 2002, bom Hotel JW Marriott tahun 2003, bom Kedutaan Besar Australia tahun 2004, dan bom Bali II tahun 2005. Untuk returnis TKT gelombang kedua, jeda waktu yang mereka 
habiskan lebih kurang sama, yaitu sekitar 3 tahun sejak kepulangan mereka tahun 2004, dan aksi-aksi yang mulai terlihat, yaitu aksi teror bom di Poso tahun 2007, bom Hotel JW Marriott dan Ritz-Carlton tahun 2009, pelatihan di hutan Jantho Aceh tahun 2010, bom Kantor Polisi Cirebon tahun 2011.

Pasal 16 PERPU No. 1/ 2002 tentang Pemberantasan Tindak Pidana Terorisme telah menetapkan sanksi bagi setiap individu di luar negara Indonesia yang memfasilitasi (memberi bantuan, kemudahan, sarana) terjadi terorisme di Indonesia. Kesulitan dari penerapan pasal ini adalah pada pembuktian seseorang melakukan suatu "fasilitasi" yang menghasilkan suatu tindak pidana terorisme. Salah satu solusi yang bisa diterapkan adalah penetapan organisasi atau individu tertentu sebagai entitas terorisme, sehingga pembuktian yang dilakukan cukup dalam hal membuktikan afiliasi atau hubungan seseorang dengan organisasi terorisme tertentu, baik di dalam maupun luar negeri. PERPU No.1/2002 telah memungkinkan dijatuhkannya sanksi kepada pengurus korporasi atau entitas terorisme, yaitu jika korporasi tersebut terbukti melakukan aksi terorisme atas nama dirinya. Tetapi hubungan seseorang dengan organisasi terorisme tidak dikriminalisasi di dalam PERPU No. 1/2002 yang kemudian menjadi UU No. 15/2003 (UU Anti-Terorisme/ UU AT) tersebut. Penerapan pasal 16 ini membutuhkan kemampuan anti-terorisme yang mumpuni dalam melacak dan membuktikan keanggotaan atau asosiasi seseorang terhadap jaringan terorisme.

Oleh karena itu, pengembangan kekuatan kontra-terorisme yang mengikuti dilegislasikannya PERPU No/1/2002 menjadi undang-undang melalui UU No.15/2003 terkonsentrasikan pada kemampuan penegak hukum, khususnya Detasemen Khusus Anti-Teror (Densus
88) dalam melakukan penangkapan yang mendisrupsi sel-sel teroris dan sistem peradilan dalam mempidanakan anggotaanggota dari sel-sel tersebut. Australia dan Amerika Serikat menjadi pendana utama upaya pengembangan kekuatan kontra-terorisme berbasis criminal justice ini. Tetapi pengembangan kemampuan kontra-terorisme Indonesia pasca reformasi meninggalkan pekerjaan rumah besar pelibatan lembaga-lembaga keamanan dan pertahanan, karena kontinuitas serangan terorisme yang difasilitasi returnis TKT masih berlanjut pasca Bom Bali tahun 2002. Meskipun Densus 88 baru dibentuk tahun 2004, tetapi unit-unit khusus anti-terorisme telah ada di tubuh TNI, dan lembaga ini juga memiliki jaringan teritorial yang dapat menjadi asset pengumpulan intelijen yang dapat memperkuat Densus 88.

Keberlanjutan aksi terorisme pasca Bom Bali tahun 2002 menunjukkan bahwa hal ini tak terjadi. Aksi serangan yang diinstruksikan dan diorganisir returnis TKT terbukti memiliki daya ledak yang lebih tinggi dan menarik lebih banyak atensi. Rangkaian pemboman tahun 2003. 2009 yang diorganisasikan oleh Noordin Muhammad Top dan Azahari yang jaringannya telah tercerai-berai akibat penindakan kontra-terorisme pemerintah tapi tetap mempertahankan eksistensinya; termasuk dalam rangkaian pemboman ini adalah bom di Hotel J.W. Marriott (2003), Kedutaan Besar Australia (2004), Bali yang kedua kali (2005), Hotel RitzCarlton (2009). ${ }^{26}$ Rangkaian serangan bom ini menandakan bahwa meskipun jaringan radikal terorisme lokal telah tercerai-berai dan tak mampu melakukan aksi sendiri, keberadaan elemen transnasional berupa beberapa orang alumni atau veteran

26 Bruce Vaughn et al., Terrorism in Southeast Asia (New York: Nova Science Publishers, 2008). 
konflik internasional membuat jaringan yang tercerai-berai pun jadi mematikan. Mereka lah yang mempengaruhi kelompokkelompok jihadis lokal dalam menentukan penentuan target, perencanaan dan eksekusi operasi. ${ }^{27}$ Keberadaan operator yang memiliki keterampilan tempur juga mendorong penyelundupan senjata dan pengumpulan dana yang dibutuhkan untuk melanjutkan aktivisme jihadis.

Dapat dikatakan bahwa pengembangan kekuatan kontra-terorisme Indonesia hanya menekankan kemampuan penangkapan dan pemidanaan tanpa memperhatikan proses yang terjadi dalam penahanan dan pasca penahanan. Akibatnya, tahun 2010 ditandai dengan 'siklus daur ulang' pelaku terorisme. Kelompok-kelompok jihadis lokal seperti Komite Aksi Penanggulangan Akibat Krisis (KOMPAK), JI, JAT, Ring Banten tidak pernah benar-benar berakhir, tapi mereka kekurangan kepemimpinan, struktur organisasi dan tujuan setelah kematian returnis TKT Noordin Top pada 2009 dan fokus Ba'asyir pada dakwah. ${ }^{28}$ Peran pengorganisasian serangan dimainkan oleh returnis TKT lain bernama Dulmatin yang mengajak serta Oman Abdurrahman, untuk mendirikan Lintas Tanzim atau lintas organisasi untuk mendirikan pelatihan militer di Aceh dengan nama Al Qaeda Indonesia Wilayah Serambi Mekkah. ${ }^{29}$ Pembangunan pelatihan militer ini akhirnya

27 Thomas Hegghammer, "Should IStay or Should IGo? Explaining Variation in Western Jihadists' Choice between Domestic and Foreign Fighting," American Political Science Review 107, no. 1 (February 2013): 11-12, doi: 10.1.017/S0003055412000615. 191

28 Kirk A. Johnson, "The Longue Duree: Indonesia's Response tothe Threat of Jihadist Terrorism 1998-2016" (Naval Postgraduate School, 2016), http://calhoun. nps.edu/bitstream/handle/10945/49499/16Jun Johnson_Kirk.pdf?sequence $=1$.

29 Paul J Carnegie, "Is Militant Islamism a Busted Flush in Indonesia?," Journal of Terrorism Research 4, no. 2 (2013): 14-25. gagal karena tidak banyak warga Aceh yang bergabung dan laporan dari masyarakat yang direspons oleh kepolisian setempat dan Densus 88.

\section{Perubahan Karakter Terorisme dan Eskalasi Kontra-Terorisme}

Ancaman NIIS baru terekspesikan di ranah publik sejak kebahayaan dari aliran WNI ke Suriah mulai menjadi pembahasan publik di tahun 2014, seiring dengan semakin banyaknya praktik ber-bai'at atau menyatakan kesetiaan kepada NIIS yang dilakukan secara publik. Persaingan antara Al-Qaeda dan NIIS berimplikasi pada negara-negara yang memiliki simpatisan dan pengikut untuk keduanya, termasuk Indonesia. Ini termanifestasikan pada perpecahan di tubuh gerakan jihadisme Indonesia antara Jemaah Islamiyah yang mengutamakan terbentuknya masyarakat yang mendukung negara Islam dan pengikut NIIS yang mengutamakan terbentuknya suatu kedaulatan Islam dan ikut mempertahankannya di mana pun berada, baik Suriah, Filipina, maupun tempat lain. Kenyataannya, fragmentasi JI meninggalkan sejumlah kelompok pecahan - termasuk Mujahidin Indonesia Timur yang tetap terlibat dalam aktivitas terorisme dan salah satu kelompok pecahan itu pun dibentuk oleh mantan amir JI Abu Bakar Ba'asyir yang kemudia berbai'at kepada NIIS dan membentuk Jemaah Ansharut Tauhid. Dengan kata lain, "proyek jihadisme" yang sempat bisa dipastikan tak berdaya setelah tewasnya Dulmatin dan tertangkapnya Ba'asyir pada akhir 2010, ternyata meninggalkan warisan sumber daya manusia dan kepemimpinan untuk kelompok-kelompok pro-NIIS pada 2011 hingga tulisan ini dibuat.

Faksi-faksi ekstrimis yang sudah ada di Indonesia sejak sebelum kehadiran NIIS 
menjadi fasilitator inkubasi ideologis dan aksi pro-NIIS. Fitriani $\mathrm{dkk}$ menjelaskan adanya empat faksi jihad-kekerasan yang kembali aktif dan bersalin rupa menjadi jaringan pro-NIIS setelah JI kehilangan daya geraknya, yaitu Forum Aktivis Syariat Islam (FAKSI), Tauhid wal Jihad, Front Pembela Islam (FPI) Cabang Lamongan, dan Jemaah Ansharut Tauhid (JAT). ${ }^{30}$ Keempatnya pada tahun 2015 bergabung menjadi Jemaah Ansharut Daulah (JAD), dengan Aman Abdurrahman dan Abu Bakar Ba'asyir sebagai pemimpin spiritual dan Abu Husna sebagai pemimpin operasional. Terlepas dari status kelompok JAD yang sebenarnya, penjelasan ini menunjukkan bahwa kebahayaan lain dari NIIS di Indonesia adalah re-organisasi dan re-aktivasi faksifaksi jihad-kekerasan di Indonesia pasca pelemahan JI era 2003-2013.

Sejak 2012, gelombang ketiga WNI yang berpergian ke wilayah konflik mulai menjadi menjadi kombatan dalam perang saudara di Suriah. Catatan Kepala 'Satgas FTF' Densus 88 AKBP Didik Novi Rahmanto menunjukkan bahwa jumlah WNI yang menjadi TKT di Suriah dan Iraq sejak 2014 mencapai total 1580 orang, dan pada 2019 masih ada 639 orang Indonesia di Suriah. Sejak 2012, aliran WNI yang berhijrah ke wilayah konflik untuk menjadi TKT kembali terjadi, kali ini dengan tujuan Suriah. Tidak seperti keberangkatan WNI ke Afghanistan di era 1980-an dan 1990-an yang tersentralisasi dan selektif, keberangkatan WNI ke Suriah lebih merupakan proses yang individual atau kelompok kecil dengan agen keberangkatan yang berbedabeda, akibatnya WNI yang menjadi TKT di Suriah menghadirkan persoalan kategorisasi yang pelik, karena di antara mereka ada

30 Fitriani et al., "The Current State of Terrorism in Indonesia: Vulnerable Groups, Networks, and Responses," CSIS Working Paper Series, 2018, 19, https://doi.org/10.1111/j.1442-9071.2008.01717.x. yang tidak menjadi kombatan dan ada pula para deportan. ${ }^{31}$ Sejumlah mahasiswa Indonesia di Yaman, Mesir, Turki dan Pakistan menjadi "angkatan" pertama yang berangkat; mereka membayar sendiri biaya perjalanan dengan arahan dari panitia lokal yang bersifat ad hoc dan melekat di lembaga-lembaga pengajian lokal yang berafiliasi dengan individu TKT yang telah aktif di Suriah, yang selanjutnya berperan untuk memberikan tazkiyah atau surat rekomendasi kepada mereka yang dianggap layak untuk berangkat. ${ }^{32}$ Mekanisme serupa berupa pemberian tazkiyah oleh mereka yang sudah terlebih dulu berada di wilayah NIIS juga terjadi untuk para TKT yang berasal dari Eropa Barat. ${ }^{33}$ Ini menandakan tidak ada TKT yang berangkat ke Suriah dengan tujuan hidup di wilayah NIIS tanpa sebelumnya menjalin kontak dan memiliki koneksi dengan jaringan afiliasinya.

Pada bulan Desember 2016 Kepala BNPT Suhardi Alius melaporkan bahwa warga Indonesia yang pernah bergabung dengan NIIS berjumlah 460, dan sebagian diketahui berhubungan dengan jaringan terorisme di Indonesia. ${ }^{34}$ Strategi NIIS yang mengutamakan kehadiran yang luas dan

31 IPAC, "Indonesians and the Syrian Conflict," 29 January 2014, diakses pada 4 April 2016, http:// www.understandingconflict.org/en/conflict/read/22/ Indonesians-and-the-Syrian-Conflict

32 "Pelajar Indonesia ikut ISIS, nasihat orang tua tak didengar," Tempo, 31 Maret 2015, diakses 4 April 2017, http://nasional.tempo.co/ read/ news/2015/03/31/078654206/pelajar-indonesiaikut-isis-nasihat-orang-tua-tak-didengar and "Anak muda anggap ISIS seru dan menantang," Tempo, April 1, 2015, , diakses 4 April 2017, http://nasional. tempo.co/read/news/2015/04/01/ 078654413/anakmuda-anggap-isis-seru-dan-menantang. 80.

33 Francesco Marone, "Ties That Bind: Dynamics of Group Radicalisation in Italy's Jihadists Headed for Syria and Iraq," International Spectator 52, no. 3 (2017): 48-63, https://doi.org/10.1080/03932729.2 017.1322800.

34 KOMPAS, 2 Desember 2016, h. 3 
kuat di ruang siber dan media informasi lain membuat mereka berinvestasi untuk melakukan sebanyak mungkin serangan, meski dengan persiapan dan sarana minim, untuk mengklaim serangan-serangan tersebut. Semakin kuat profil mereka terbangun lewat serangan kepada mereka yang dianggap bertentangan dengan Islam, semakin banyak rekrutmen dapat terjadi untuk kepentingan serangan maupun propaganda.

Kebahayaan TKT telah muncul bahkan sebelum yang bersangkutan menjadi returnis, yaitu dengan mengarahkan serangan di tanah air (directed attack). Salah satu sosok TKT yang memainkan peran ini bernama Bahrun Naim, seorang mantan anggota Hizbut Tahrir Indonesia (HTI) yang ditahan aparat karena kepemilikan senjata dan amunisi. Bahrun Naim memiliki jaringannya sendiri, termasuk Tim Hisbah di Solo dan Mujahidin Indonesia Timur yang dipimpin Santoso dan berbasis di Poso. ${ }^{35}$ Peran Bahrun Naim adalah menyemangati, mengarahkan dan mendanai operasi di Indonesia, termasuk serangan yang direncanakan terjadi di markas polisi dan gereja pada 17 Agustus 2015 di Solo dan pada malam pergantian tahun 2015 di Jakarta, rencana serangan terhadap Istana Presiden pada 11 Desember 2016 oleh Dian Yulia Novi. Bahrun Naim akhirnya terbunuh di Suriah pada November 2017. ${ }^{36}$ Selain Bahrun Naim, TKT lain yang mengorganisasikan jaringan lokalnya di Indonesia untuk melakukan aksi serangan adalah Bachrumsyah yang berangkat ke

35 Kumar Ramakrishna, "The Growth of ISIS Extremism in Southeast Asia: Its Ideological and Cognitive Features-and Possible Policy Responses," New England Journal of Public Policy 29, no. 1 (2017).

36 Poltak Partogi Nainggolan, "Kekhalifahan ISIS Di Asia Tenggara, Sekedar Wacana Atau Realitas," Politica 8, no. 2 (2017): 205-30.
Suriah pada Mei 2014, dan pada Januari 2016 berhasil mengorganisasikan serangan terorisme di Sarinah Thamrin, Jakarta. ${ }^{37}$ Melalui pengiriman dana yang diberikan kepada seorang Hendro Fernando yang kemudian merekrut empat individu anggota Jemaah Anshar Khilafah (JAK) pimpinan Oman Abdurrahman untuk melakukan aksi, Bachrumsyah berhasil mengarahkan dan mengorganisasikan serangan tersebut. ${ }^{38}$ Pada bulan Juni 2017, kebahayaan dari returnis TKT dengan aksi terorisme yang dilakukan seorang returnis bernama Syawaluddin Pakpahan yang ke Suriah dan bertempur bersama Free Syrian Army; ia menusuk hingga tewas seorang petugas kepolisian di Medan. ${ }^{39}$

Akhirnya, peledakan bom bunuh diri di Surabaya, menarget tiga gereja pada 13 Mei 2018 dan Kantor Polrestabes pada 14 Mei 2018 dilakukan oleh dua keluarga yang berafiliasi dengan Jemaah Ansharut Daulat (JAD). Dua keluarga ini bukan returnis Suriah, meski serangan-serangan yang mereka lakukan diklaim oleh NIIS dan JAD sendiri merupakan kongregasi kelompokkelompok jihadi lokal Indonesia yang telah menyatakan kesetiaan kepada NIIS. Hubungan transnasional apa yang terjadi di balik serangan-serangan di Surabaya, baik dukungan finansial, operasional atau pilihan target masih membutuhkan kajian yang lebih dalam. Tetapi karakter gerakan terorisme yang kini memprioritaskan aksiaksi individual dan mendayagunakan proses

37 Ali Abdullah Wibisono, "Fundamental Issues in Counterterrorism," The Jakarta Post, 26 Januari 2016.

38 Zachary Abuza, "The Strategic and Tactical Implications of the Islamic State on Southeast Asia's Militant Groups," Georgetown Journal of Asian Affair, Fall (2016): 20-30.

39 Chaula R. Anindya, "Assessing the Threats of Returnees and Deportees in Southeast Asia: A Case Study of Malaysia and Indonesia", Thinking ASEAN, issue 34, April 2018 
radikalisasi yang tak dilakukan melalui jaringan terorisme yang ada sebelumnya memberikan justifikasi bagi pemerintah untuk meningkatkan kapasitas preventif dari penanggulangan terorisme.

Kemampuan disrupsi sel-sel terorisme semakin kuat dengan revisi undang-undang anti-terorisme yang mengeskalasikan kemampuan pemerintah untuk melakukan penangkapan terduga teroris dan menahan mereka untuk penyelidikan dan penyidikan hingga maksimal 290 hari (pasal 25, 28, dan 28A), menggunakan kekuatan angkatan bersenjata (pasal 43i), melakukan penyadapan (pasal 31 dan 31A), melakukan penangkapan berdasarkan keanggotaan individu pada organisasi terorisme (pasal 12A), dan menggunakan motif ideologi, politik dan gangguan keamanan untuk mengidentifikasi terorisme (pasal 1)..$^{40}$

Pengembangan kemampuan disrupsi sel-sel terorisme tidak diikuti dengan kemampuan deradikalisasi dan reintegrasi mantan pelaku terorisme. Kemampuan negara untuk mengupayakan rehabilitasi dan reintegrasi sosial terhadap para returnis pun belum meyakinkan. Kajian awal terhadap proses rehabilitasi yang diupayakan oleh Kemensos RI terhadap deportan yang tidak memiliki catatan kriminal dapat menjadi gambaran awal kesiapan Indonesia melakukan rehabilitasi para returnis. Hingga sejauh ini rehabilitasi masih dilakukan dengan ketiadaan panduan yang jelas. Sementara itu ada masalah ego sektoral, tumpang tindih wewenang antara lembaga negara dan organisasi-organisasi non-pemerintah yang masih menghalangi proses reintegrasi yang efektif. Selain itu ada persoalan information-sharing yang kurang antar pemangku kepentingan karena

40 Republik Indonesia, Undang-Undang No. 5/2018 tentang Perubahan atas Undang-Undang No.15/2003 tentang Penetapan PERPU No.1/2002 Menjadi Undang-Undang. kompetisi di antara mereka. Deportan ditangani oleh terlalu banyak "tangan" sehingga menyulitkan untuk evaluasi program apa yang sebenarnya efektif. ${ }^{41}$

Program repatriasi dan reintegrasi deportan di Indonesia bersentral pada peran lembaga non-pemerintah. Kesulitan koordinasi teridentifikasi dari kajian awal terhadap repatriasi dan reintegrasi para deportan karena pemerintah daerah tidak selalu bersedia memberikan bantuan kebutuhan dasar. Pemerintah daerah membantu tanpa ada petunjuk dan anggaran yang jelas.

Revisi Undang-Undang No. 15/2003 tentang Penetapan PERPU No.1/2002 tentang Pemberantasan Tindak Pidana Terorisme (Revisi UU AT), ditetapkan pada 25 Mei 2018, melembagakan proses penetapan entitas terorisme, pemidanaan keanggotaan dalam entitas terorisme dan keterlibatan WNI dalam gerakan terorisme internasional. Pasal $12 \mathrm{~A}$ dan 12 B dari revisi UU AT merupakan tempat pengaturan dimensi transnasional dari terorisme dalam hal keanggotaan dan pengorganisasian terorisme lintas negara. Pengaturan ini dimulai dengan pasal 12A(1) yang memidanakan perencanaan/ dan pengorganisasian terorisme "dengan orang yang berada di dalam negeri dan/atau di luar negeri atau negara asing", pasal 12A(2) yang memidanakan orang yang "sengaja menjadi anggota atau merekrut orang untuk menjadi anggota korporasi yang ditetapkan dan/atau diputuskan pengadilan sebagai organisasi terorisme", dan pasal 12 A(3) yang memidanakan "pendiri, pemimpin, pengurus, atau orang yang mengendalikan kegiatan Korporasiterorisme". Sementara pasal 12B didedikasikan untuk memidanakan

41 Chaula Rininta Anindya, "The Deradicalisation Programme for Indonesian Deportees: A Vacuum in Coordination," Journal for Deradicalization, no. 18 (2019): 217-43. 
pelatihan militer untuk kepentingan terorisme, termasuk menyelenggarakan dan berpartisipasi (Pasal 12B(1)), memberikan bantuan untuk yang berpartisipasi (Pasal $12 \mathrm{~B}(2))$, dan menyebarluaskan informasi (Pasal 12B(3)). Selain itu, pasal 12A(4) memberikan sanksi tambahan kepada mereka yang terkena salah satu atau lebih dari Pasal 12(A) (1-3) dengan pencabutan paspor setelah (Pasal 12A(5)) yang bersangkutan menjalankan sanksi yang diatur pasal 12A(1-3).

Melihat pengaturan pasal $12 \mathrm{~A}$ dan 12B dari Revisi UU AT, artikel ini menilai bahwa problematika TKT baru diatur sebagian, yaitu keanggotaan dalam korporasi dan keberangkatan untuk ikut berperang di luar negeri, tapi belum mengatur sama sekali tentang returmis atau orang yang kembali dari keikutsertaan dalam konflik di luar negeri, dan ada kerancuan tentang pidana keanggotaan/ kepengurusan korporasi terorisme.Frase "sengaja menjadi anggota atau merekrut" pada pasal 12(A) menganjurkan bahwa pemerintah harus transparan kepada publik tentang entitas mana yang mereka target sebagai entitas teroris dengan menerbitkan daftar terduga teroris dan memutakhirkan nya secara berkala.

Kekurangan pengaturan dalam menghadapi fenomena TKT jauh lebih serius. Pembatasan akses masuk bagi mereka yang sudah memilih untuk menjadi TKT di dalam konflik di luar negeri perlu mendapat pertimbangan serius, karena tanpa pembatasan akses, orang tidak akan tergentarkan dari pilihan untuk menjadi TKT. Pengaturan pasal 12B(5) yang mencabut paspor mereka yang telah menyelesaikan sanksi pidana karena memfasilitasi, berpartisipasi dan/atau menyebarkan advertensi pelatihan militer/ para militer dapat diterima, tetapi perlu dibedakan antara mereka yang melanggar pasal 12B(1) (berangkat menjadi TKT) dan yang tidak. Orang yang bergabung kelompok militan di luar negeri, terlebih yang sudah masuk ke dalam daftar entitas terorisme dari DK-PBB, seyogyanya dipersepsikan sederajat dengan mereka yang dengan sengaja bergabung dengan korporasi terorisme sebagaimana diatur pada pasal $12 \mathrm{~A}$.

\section{Perkembangan Rezim Internasional}

Rezim internasional terdiri dari serangkaian konvensi internasional yang memberi Batasan kebijakan pemerintah, dalam hal ini diwakili oleh resolusi Dewan Keamanan Perserikatan Bangsa-Bangsa (DK-PBB). Bagian penting dari respons terhadap teroris-kombatan transnasional adalah penetapan organisasi yang ditarget sebagai entitas terorisme, karena berawal dari penetapan ini anggota organisasi tersebut dapat dilacak dan ditindak. Dalam hal ini lah resolusi DK-PBB membantu Indonesia; selain itu, resolusi DK-PBB juga mendorong terjadinya kriminalisasi terhadap teroris-kombatan transnasional itu sendiri.

Kontra-terorisme Indonesia pada awal penerapan undang-undang Anti-Terorisme tidak menentukan siapa yang ditarget dengan kebijakan itu. Panglima TNI Endriartono Sutarto mengatakan bahwa pemerintah tidak memerangi kelompok tertentu dalam perangnya melawan terorisme. ${ }^{42}$ Proses penyidikan tersangka Bom Bali yang tertangkap antara tahun 2003 dan 2009 juga tidak diasosiasikan dengan organisasi apa pun. Individu-individu yang diproses muncul ke wacana publik sebagai individu yang bekerja dalam sel-sel terpisah dengan

42 Media Indonesia, "TNI telah mempersiapkan Unit Anti-Teror untuk Bantu Polisi”, 31 Oktober 2002, h. 5 
koneksi bebas dengan Jemaah Islamiyah. Kebijakan penetapan teroris dilakukan pemerintah dengan mengikuti penetapan organisasi terorisme yang dilakukan Perserikatan Bangsa-Bangsa (PBB) atau mengakui penetapan organisasi teroris yang dilakukan negara lain. ${ }^{43} \mathrm{JI}$ terdaftar sebagai organisasi teroris lewat Resolusi Dewan Keamanan PBB No. $1267 .{ }^{44}$ Seiring dengan penetapan JI sebagai organisasi teroris oleh $\mathrm{PBB}$ dan negara-negara lain, pemerintah pun berjanji menindak warganya yang terlibat dalam JI. ${ }^{45}$

Mekanisme penetapan entitas terorisme di Indonesia difasilitasi oleh Resolusi DK-PBB 1267 yang mengatur penetapan entitas-entitas yang berasosiasi dengan $\mathrm{Al}$ Qaeda dan Taliban, dan memberi mandat kepada seluruh negara anggota untuk memperbaharui daftar bernama "Al-Qaida Sanctions List" yang berisi organisasi, individu, jaringan (undertaking) dan entitas yang berasosiasi dengan $\mathrm{Al}$ Qaeda dengan menambah maupun menghapus nama tertentu. Resolusi 1267 telah diperbaharui beberapa kali, termasuk pada tahun 2015 (Resolusi DK-PBB 2253) yang mengganti nama daftar menjadi "ISIL (Da'esh) $\mathcal{E} \mathrm{Al}$ Qaida Sanctions List" yang mengakui ISIL sebagai kelompok pecahan (splinter group) dariAl-Qaida.Kriteriayangdigunakandalam Resolusi 2253 untuk menentukan suatu entitas terinklusi ke dalam "ISIL (Da'esh) Eु Al-Qaida Sanctions List" adalah bahwa ketika entitas tersebut melakukan aksi atas nama, lewat asosiasi dengan mendukung

43 KOMPAS, "Ba'asyir Ditetapkan Sebagai Tersangka", 18 Oktober 2002, h. 1

44 UNSC Res 1267 (15 Oktober 1999) UN Doc S/ RES/1267; United Nations Security Council, "AlQaeda Sanctions List", menyebutkan "Jemaah Islamiyah operated in Indonesia, Malaysia, and the Philippines".

45 KOMPAS, "Jemaah Islamiyah terdaftar sebagai Organisasi Teroris oleh PBB”, 27 Oktober 2002, h. 3
ISIL \& Al-Qaida maupun turunan, pecahan, dan afiliasinya, aksi tersebut berupa: 1) partisipasi dalam pendanaan, perencanaan, fasilitasi, persiapan dan pengeksekusian aksi; 2) menyuplai, menjual atau mentransfer senjata dan material yang berhubungan dengan senjata; 3) merekrut atau mendukung aktivitas dan perbuatan. ${ }^{46}$

Secara umum, Resolusi DK-PBB untuk terrorist-listing memberikan keleluasaan bagi pimpinan eksekutif untuk menempatkan entitas-entitas tertentu kepada Security Council Committee sebagai entitas terorisme lewat deklarasi sepihak (oleh eksekutif), atau menggunakan proses peradilan untuk menetapkan entitas tertentu sebagai teroris. Kedua proses ini mengantisipasi kelemahan hukum anti-terorisme negara anggota yang belum tentu dapat mengklasifikasikan perbuatan atau aktor tertentu sebagai terorisme, sementara entitas tersebut telah mengakibatkan bahaya bagi keselamatan publik karena aksinya sulit diintervensi. Untuk memfasilitasi pencegahan yang lebih dini, negara dapat terlebih dahulu memperbaharui "ISIL $\&$ Al-Qaida Sanctions List" sebelum memperbaharui undangundangnya lewat tindakan ini, seluruh negara anggota PBB mendapat mandat untuk menghentikan atau mempersempit ruang gerak entitas yang dimasukkan ke dalam daftar tersebut.

Resolusi DK-PBB 1267 yang mengidentifikasi Jemaah Islamiyah sebagai organisasi terorisme tidak diindahkan sebelum PERPU No.1/2002 terbit, dan menamai atau memberi status entitas tertentu sebagai teroris menjadi kesulitan yang mengikuti sesudah PERPU itu dilegislasikan. Ketika itu, pemerintah mengatakan bahwa entitas dengan nama

46 UNSC Res 2253 (17 Desember 2015), http://www. un.org/en/ga/search/view_doc.asp?symbol=S/ RES/2253(2015) 
yang bermakna "komunitas Islami" tak layak dikategorikan sebagai teroris. Aktor-aktor keamanan cenderung tak sepakat dalam mengkategorisasikan organisasi tertentu sebagai entitas terorisme antara keinginan Badan Intelijen Keamanan POLRI agar kelompok yang terbukti melakukan aktivitas terorisme dan organisasi yang mendukung berdirinya negara Islam diberi label organisasi terorisme dan terlarang dan keinginan Badan Intelijen Strategis TNI yang meyakini bahwa penetapan sebagai organisasi terorisme dan pelarangan justru membuat kelompok-kelompok terorisme bergerak di bawah tanah dan menyulitkan pelacakan. Di tengah ketidaktetapan prinsip dan prosedur penetapan entitas terorisme, Pengadilan Negeri Jakarta Selatan pada bulan April 2008 memutuskan bahwa Jemaah Islamiyah ditetapkan sebagai organisasi terlarang; ${ }^{47}$ Keputusan ini diambil ketika pemerintah pusat sendiri belum menentukan kejelasan sikap. Preseden ini baru diadaptasi oleh pemerintah pusat ketika membuat respons kebijakan menghadapi NIIS dan pendukungpendukung domestiknya.

Revisi UU No.15/2003 yang dimulai pasca tragedi Bom Sarinah Thamrin pada Januari 2016 sebenarnya merupakan momentum untuk memperkuat legislasi yang secara khusus merespons returnis TKT secara selektif, tetapi hal ini dalam diskursus publik Indonesia terlalu erat diasosiasikan dengan solusi pencabutan kewarganegaraan yang merupakan hak dasar setiap individu, ${ }^{48}$ sehingga ada dorongan yang kuat dari publik untuk lebih mengedepankan

47 Nurfarahislinda M Islami, Vidia Arianti, \& Jennifer Yang Hui, "The Surprise Verdict: The Proscription of Jemaah Islamiyah," RSIS Commentary, 19 Juni 2008.

48 KOMPAS, "Polri Masih Sulit Memidana, Sanksi Pencabutan Kewarganegaraan Ditentang", 19 Juli 2017, h. 3 prinsip kemanusiaan kepada para deportan dan returnis. ${ }^{49}$ Akhirnya, revisi UU Anti-Terorisme, yaitu UU No.5/2018, menerapkan pencabutan paspor kepada mereka yang menjadi TKT setelah mereka kembali ke tanah air dan menjalankan sanksi pidana penjara, ${ }^{50}$ ditambah dengan mandat kepada BNPT untuk melakukan koordinasi upaya deradikalisasi. Dengan kata lain, belum ada mekanisme sama sekali untuk mencegah kepergian TKT dan menerapkan asesmen risiko yang selektif bagi returnis.

Prosedur penetapan entitas atau aktor tertentu sebagai teroris baru diterbitkan dalam aturan formal pada era pemerintahan Presiden Joko Widodo lewat Peraturan Bersama Ketua Mahkamah Agung, Kapolri, Kepala BNPT, dan Kepala PPATK tahun 2015 Tentang Pencantuman Identitas Orang dan Korporasi Dalam Daftar Terduga Teroris dan Organisasi Teroris dan Pemblokiran Secara Serta Merta Atas Dana Milik Orang atau Korporasi yang Tercantum Dalam Daftar Terduga Teroris dan Organisasi Teroris mengatur pencantuman individu dan korporasi terduga teroris yang bersumber dari Pemerintah dan Perserikatan Bangsa-Bangsa. ${ }^{51}$ Dengan peraturan bersama ini, pemblokiran dana yang berasal dari dan ke individu dan korporasi yang sudah ditetapkan oleh Pemerintah dan/atau PBB dapat dilakukan dengan lebih cepat

49 Noor Huda Ismail, Amunisi Baru Melawan Ideologi NIIS, KOMPAS, 28 Agustus 2017, h. 7

50 KOMPAS, "Sanksi Baru Diatur, WNI Ikut Kelompok Teroris Asing Bisa Dipidana", 17 Juni 2017, h. 4

51 Kementerian Hukum dan HAM, "Peraturan Bersama Ketua Mahkamah Agung, Menteri Luar Negeri, Kepala Kepolisian Negara, Kepala Badan Nasional Penanggulangan Terorisme, Dan Kepala Pusat Pelaporan Dan Analisis Transaksi Keuangan Nomor 01/PB/MA/II/2015, 03, 1, B.66/K. BNPT/2/2015 Dan Nomor 0," Pub. L. No. 1/PB/ MA/II/2015, 03, 1, B.66/K.BNPT/2/2015 \& 01/1.02/ PPATK/2/2015 (2015), https://doi.org/10.1093/ bioinformatics/btk045. 
dan dipatuhi oleh instansi pemerintahan yang diatur dalam peraturan ini. Maka dana yang berasal dari dan ke Indonesia dari individu atau korporasi yang sudah ditetapkan sebagai entitas teroris oleh PBB dapat dibekukan sebelum mendanai aksi terorisme.

Respons legal-formal yang mutakhir dari pemerintah terhadap fenomena TKT tercantum dalam UU No.5/2018 pasal $12 \mathrm{~B}$ yang memidanakan penyelenggaraan, pemberian, partisipasi dalam pelatihan militer atau paramiliter di dalam dan luar negeri dengan tujuan merencanakan, mempersiapkan atau melakukan aksi terorisme dan/atau perang di luar negeri; perekrutan, penampungan atau pengiriman orang untuk pelatihan, maupun segala bentuk tindakan kampanye atau promosi pelatihan militer dan para militer di luar negeri, dengan pidana maksimal 15 tahun penjara dan pencabutan paspor. ${ }^{52}$

Respons Indonesia terhadap TKT yang mewujud secara resmi dalam UU No.5/2018 tak terlepas dari dorongan rezim internasional PBB. Resolusi PBB berkenaan dengan TKT telah muncul pada Resolusi DK-PBBNo.2178/2014, yang memandatkan negara-negara anggota untuk merespons underlying factors yang memungkinkan terjadinya TKT, termasuk penyebaran pesan ekstremisme, pendanaan terorisme dan ketiadaan inhibitor bagi perjalanan TKT. Berkenaan dengan lalu-lintas para TKT, Resolusi DK-PBB 2368 tahun 2017, yang memutakhirkan Resolusi 2253, tidak memberikan mandat spesifik kepada negaranegara anggota selain memberikan informasi kredibel tentang individu-individu tertentu yang diyakini secara objektif terlibat dalam aktivitas terorisme dan berusaha untuk

52 Republik Indonesia, Undang-Undang No. 5/2018 tentang Perubahan atas Undang-Undang No.15/2003 tentang Penetapan PERPU No.1/2002 Menjadi Undang-Undang. masuk ke dalam wilayah suatu negara, dan tidak membiarkan wilayah negara nya menjadi tempat aktivitas maupun transit bagi TKT. Berkenaan dengan TKT yang kembali sebagai returnis di negara asalnya, Resolusi DK PBB 2368 memberikan diskresi kepada negara-negara anggota untuk menolak kembalinya mereka (entry) atau memproses pidana yang mereka lakukan selama menjadi TKT.

\section{Teroris-Kombatan Transnasional dalam Pembahasan Revisi Undang-Undang Tentang Pemberantasan Tindak Pidana Terorisme di DPR-RI}

Terhadap pasal 12B dari Draft Revisi UU Anti-Terorisme, beragam sikap muncul dari berbagai fraksi di DPR berkaitan dengan spesifitas pembuktian dari tujuan dari pelatihan militer untuk perencanaan, persiapan dan pelaksanaan tindak pidana terorisme. Pembuktian ini dianggap perlu oleh sebagian fraksi, misalnya Fraksi PKB, karena kaitan antara kegiatan pelatihan militer atau para militer dengan tindak pidana terorisme adalah sesuatu yang harus dibuktikan. Sementara fraksi-fraksi lain termasuk F-PDIP, F-Gerindra dan F-PG sepakat dengan substansi yang ada dengan maksud meningkatkan kemampuan aparat melakukan deteksi dini. Perdebatan yang terjadi berkenaan dengan pengaitan pelatihan militer dengan tindak pidana terorisme dapat dijelaskan dengan konteks Indonesia yang sebelumnya tidak pernah melakukankriminalisasiterhadapperjalanan seseorang ke luar negeri untuk bergabung dengan suatu pelatihan militer atau para militer, meskipun akhirnya pelatihan tersebut mendukung terlaksananya suatu aksi terorisme. Kriminalisasi yang dilakukan oleh PBB terhadap kombatan transnasional (foreign fighter) dengan mengimbuhkan kata teroris sehingga menjadi teroris-kombatan 
transnasional (foreign terrorist-fighter) ikut memberi tekanan kepada pemerintah Indonesia untuk mulai melakukan kriminalisasi terhadap fenomena ini. Tekanan ini pun secara efektif menghasilkan kesepakatan untuk memberikan wewenang kepada aparat menerapkan kerangka berpikir pemidanaan pada semua bentuk pelatihan para militer oleh warga sipil, seperti yang dapat kita lihat pada kesepakatan di antara fraksi-fraksi di DPR-RI.

Komponen kedua dari pengaturan tentang teroris-kombatan transnasional adalah berkenaan dengan kampanye atau penyebarluasan informasi tentang pelatihan militer atau para-militer. Dalam hal ini, anggota DPR-RI Pansus Revisi UU AT juga memunculkan diskursus kehatihatian dalam pembuktian pidana, karena yang menjadi target pemidanaan adalah penyebarluasan informasi tentang pelatihan militer, bukan persiapan, perencanaan atau pelaksanaan aksi terorisme. Penyebarluasan informasi tentang pelatihan militer belum tentu mewujud menjadi suatu tindak pidana terorisme, sementara informasi semacam itu tersebar luas di ruang siber sehingga penerapannya dapat mengakibatkan pemidanaan terhadap banyak individu. Diskursus yang bersifat pengingat ini disampaikan antara lain oleh F-PKB, sementara F-PPP kembali menekankan pentingnya pembuktian sebab-akibat dari suatu tindakan atau aktivitas yang menjadi pokok pidana, bukan pemidanaan intensi. Sementara itu F-PDIP dan F-PG menerima substansi pasal ini sepenuhnya, dan fraksifraksi lain cenderung abstain, menandakan suatu kesetujuan terhadap pentingnya pengaturan terhadap penyebarluasan informasi yang mengarahkan penerimanya ikut serta dalam pelatihan militer, tetapi belum bisa menyetujui pemidanaan terhadap penyebaran informasi tersebut.
Pansus Revisi UU AT juga sebagian tidak dapat menerima pasal pemidanaan terhadap pelatihan militer yang dimaksudkan untuk melepaskan suatu wilayah dari suatu negara sahabat dari kekuasaan pemerintah negara tersebut. Pengaturan ini merupakan upaya pemidanaan terhadap warga negara yang ikut serta dalam organisasi serupa NIIS yang melakukan pemerintahan mandiri dari pemerintah Suriah, sehingga mencerminkan upaya pemerintah merespons fenomena kombatan transnasional. ${ }^{53}$ Penolakan sebagian anggota Pansus mengartikulasikan keberatan menyamakan terorisme dengan separatisme. Pemidanaan untuk mereka yang bergabung dengan terorisme yang separatis juga tak dapat diterapkan pada scenario yang serupa dengan bergabungnya para foreign fighters dengan Al-Qaeda di Afghanistan, karena Al-Qaeda dilindungi oleh Taliban yang merupakan pemerintah efektif di sejumlah besar wilayah negara tersebut. Hanya F-PDIP, F-PG, dan F-NasDem yang menyatakan kesetujuannya terhadap substansi yang akhirnya tak diloloskan sebagai salah satu ayat dari pasal 12B ini, karena mereka - terutama F-PG - mengkategorikan tindakan mendukung separatisme di negara lain sebagai makar.

Komponen terakhir adalah pemidanaan teroris-kombatan transnasional yang berhubungan dengan kewarganegaraan yaitu pencabutan kewarganegaraan dan paspor. Pengaturan ini menjadi pertimbangan untuk menjadi salah satu pengaturan pasal 12 B, karena Resolusi DK-PBB 1278 tahun 2014 tentang Foreign Terrorist Fighter tidak melarang tetapi juga tak mewajibkan negara anggota menolak warga negara nya sendiri

53 Supriyadi Widodo Eddyono \& Ajeng Gandini Kamilah, "Sikap Fraksi DPR Dan Revisi UU Pemberantasan Tindak Pidana Terorisme: Memetakan Usulan Fraksi-Fraksi DPR Dalam Daftar Inventaris Masalah (DIM) RUU Pemberantasan Tindak Pidana Terorisme", (Jakarta: ICJR, 2017) 
masuk kembali ke wilayah mereka setelah bergabung berpartisipasi dalam aktivitas terorisme di luar negeri; tetapi resolusi DK-PBB 1278 mewajibkan negara anggota untuk menolak masuknya individuindividu ke negaranya - baik sebagai tujuan akhir maupun transit - untuk ikut serta dalam aktivitas terorisme. ${ }^{54}$ Negaranegara anggota juga wajib mengarahkan perusahaan-perusahaan penerbangan untuk memberikan advanced passenger information tentang individu-individu yang berasosiasi dengan Al-Qaeda dan NIIS yang telah meninggalkan maupun masuk ke wilayah negara kepada otoritas nasional yang relevan. Pengaturan ini menunjukkan tingginya prioritas yang ditetapkan PBB untuk menerapkan restriksi mobilitas para TKT, dan negara dapat mengupayakan hal ini lewat rekayasa kewarganegaraan dan dokumen-dokumen pendukungnya, termasuk dalam hal ini pencabutan atau penangguhan kewarganegaraan dan paspor.

Seluruh fraksi di DPR-RI sepakat untuk tidak meloloskan pidana pencabutan kewarganegaraan kepada partisipan pelatihan militer di luar negeri. Tetapi bukan masalah pemenuhan Hak Azazi Manusia, yang mengemuka melainkan kekhawatiran bahwa pecabutan kewarganegaraan justru menghalangi penerapan hukum Indonesia kepada yang bersangkutan. Pencabutan paspor menimbulkan pembelahan pendapat di antara fraksi-fraksi di DPR RI. F-PG, F-Gerindra, F-PPP, F-Partai Nasdem dan F-Hanura menyatakan tetap dengan pencabutan paspor. Tetapi F-PDIP menganggap pencabutan paspor sama dengan pencabutan kewarganegaraan dan dikhawatirkan justru menghambat penerapan hukum Indonesia pada yang

54 UNSC, "Resolution 2178 (2014) on Foreign Fighters" 2178, no. September (2014), https://undocs.org/S/ RES/2178 (2014). bersangkutan..$^{55}$ Pencabutan paspor akhirnya dimasukkan ke dalam Pasal 12B dengan catatan bahwa pidana ini diterapkan setelah seorang terdakwa pelatihan para militer di luar negeri menyelesaikan pidana penjaranya.

Implisit dalam pengaturan dari pasal 12B adalah bahwa seluruh WNI yang berpergian ke luar negeri dan bergabung dengan organisasi teroris asing, baik dalam kapasitas sebagai kombatan maupun nonkombatan harus pulang (baik atas inisiatif sendiri maupun dipulangkan) untuk menjalani proses hukum di dalam negeri dan dipidana sesuai dengan keterlibatannya. Jika terbukti bersalah, maka individu yang telah menjalani masa pidana dicegah untuk mengulangi perbuatannya (bergabung dengan organisasi teroris asing) dengan pencabutan paspor.

Sehingga dapat dikatakan bahwa proses politik domestik di Indonesia membentuk respons terhadap TKT maupun returnis TKT yang menghindari penolakan total terhadap kembalinya para veteran TKT, mantan deportan, simpatisan, dan keluarga mereka. Penolakan total yang ditandai dengan pencabutan kewarganegaraan dan izin kembali ke tanah air tak diadopsi oleh anggota-anggota legislatif. Keputusan rapat terbatas yang dipimpin Presiden Joko Widodo pada 11 Februari 2020 pun tidak menolak secara mutlak pulangnya para WNI mantan anggota NIIS, melainkan menolak "memulangkan teroris lintas batas", tetapi akan mengumpulkan data yang lebih valid tentang mereka yang bergabung NIIS. Artinya, kepulangan ini masih mungkin terjadi jika individu TKT berinisiatif sendiri untuk pulang (seperti yang dilakukan oleh

55 Ajeng Gandini Kamilah, Siti Hardiyani, \& Supriyadi Widodo Eddyono, "Pembahasan RUU Terorisme Di Panitia Khusus (Pansus) Komisi I DPR RI”, (Jakarta: ICJR, 2016), diakses pada 4 April 2018, http://icjr. or.id/data/wp-content/uploads/2016/12/21.-ProgressReport-Pansus-terorisme__Final-14-Desember-1.pdf. 
Umar Patek); sementara itu ada kategorikategori tertentu yang akan dihasilkan dari pengumpulan data oleh pemerintah, yaitu mereka yang tidak memiliki asosiasi dengan jaringan terorisme di dalam negeri sama sekali dan tidak memperlihatkan kemungkinan membangun sel-sel terorisme di dalam negeri.

\section{Pekerjaan Rumah yang Tersisa}

Dibandingkan dengan negara-negara lain sesama pengirim TKT, problematika di Indonesia terbilang moderat. Dalam perhitungan The Soufan Group, dari lima puluh negara yang diakui - baik secara resmi maupun tak resmi - sebagai negara pengirim TKT, Indonesia berada di peringkat ke-11 dengan jumlah TKT yang ke Suriah per tahun 2015 mencapai kisaran 500 hingga 700 orang. ${ }^{56}$ Angka ini masih di bawah Jerman dan Inggris dengan jumlah 760 TKT, dan di atas Amerika Serikat dengan 150-250 TKT, dan Malaysia dan Filipina, masing-masing 100 TKT. Moderatnya problematika TKT di Indonesia lebih terlihat lagi ketika jumlah TKT yang berasal dari negara ini dibandingkan dengan jumlah populasi umum dan populasi muslim: dari 65 negara, Indonesia berada di peringkat 45 dengan 2,8 TKT per sejuta penduduk dan peringkat 58 dengan 3,1 TKT per sejuta penduduk muslim.

Tetapi persoalan yang muncul dari problematika TKT di Indonesia memang tidak berhenti pada perkara jumlah. Setidaknya ada tiga masalah yang masih tertinggal setelah UU No.5/2018 yang merevisi UU No.15/2003 ini dikeluarkan. Pertama adalah kerangka legal-formal belum memberikan kerangka berpikir dan bekerja untuk menyeleksi kepulangan para TKT karena administrasi kepulangan TKT dan/ atau keluarga mereka diatur secara ad hoc

56 Benmelech \& Klor, "What Explains the Flow of Foreign Fighters to ISIS?” oleh Satuan Tugas Foreign Terrorist Fighter (Satgas FTF) yang melibatkan Kementerian Luar Negeri, Kementerian Koordinator Politik, Hukum dan Keamanan, BIN dan POLRI dan dipimpin oleh Badan Nasional Penanggulangan Terorisme (BNPT). Kedua, secara prosedural anak-anak dan perempun keluarga TKT atau deportan adalah bidang kerja Kementerian Sosial, tetapi proses rehabilitasi dan reintegrasi para deportan dan returnis TKT dan keluarganya belum dibuat secara baku, sehingga standar kerja belum dan ukuran efektivitas belum ada. ${ }^{57}$ Ketiga, instrumen hukum yang ada juga belum memuat klasifikasi yang jelas terhadap seluruh kategori individu yang berpergian ke wilayah konflik dan berasosiasi dengan terorisme berikut perlakuan terhadap mereka. Langkah-langkah ini menjadi perlu karena resolusi Dewan Keamanan PBB no. 2178 memberikan mandate kepada seluruh negara anggota untuk melakukan kriminalisasi, kerjasama internasional dan pertukaran informasi, dalam memerangi ekstremisme berkekerasan dalam rangka pencegahan terorisme sebagai respons terhadap TKT. ${ }^{58}$

\section{Kesimpulan}

Returnis TKT memiliki kebahayaan yang spesifik yang belum direspons oleh pemerintah Indonesia. Kebahayaan TKT muncul dari integrasi mereka dengan jaringan jihadisme/ ekstremisme yang sudah ada sebelumnya. Lebih penting dari kebahayaan returnis TKT adalah mengisolasi jaringan ekstremisme domestik

57 Unaesah Rahmah, "Returning Indonesian IS Women and Children: What's Next?" (Singapore: RSIS, 2019).

58 Commonwealth Secretariat, "Counter-Terrorism: Measures to Fight against the Foreign Terrorist Fighter Phenomenon and the Use of ICT for the Recruitment of Terrorists," Commonwealth Law Bulletin 43, no. 3-4 (2017): 456-70, https://doi.org/ 10.1080/03050718.2017.1470797. 
dari dukungan dan saluran yang disedikan oleh jaringan ekstremisme global.

Jumlah returnis TKT yang melakukan aksi terorisme domestik tidak sebanyak teroris domestik (home-grown); tapi jika kita hendak mencegah returnis TKT melakukan serangan terorisme domestik maka window of opportunity yang tersedia tidak lama; returnis yang melakukan serangan biasanya memang memiliki intensi melakukan serangan itu sejak sebelum kepulangannya dan ingin melakukannya sesegera mungkin. Selama penangkapanbisadilakukansesegeramungkin, dan ini artinya beban pembuktian dapat dipenuhi, maka serangan terorisme domestik dari returnis TKT tersebut bisa dicegah, tetapi ini masih meninggalkan pertanyaan tentang peluang terjadinya keterlibatan (reengagement) pasca pemenjaraan.

Respons pemerintah Indonesia terhadap TKT dipengaruhi oleh keberadaan rezim internasional - sebagaimana ditunjukkan oleh keberadaan resolusi DK PBB dan proses politik domestik, ketimbang analisis kebahayaan returnis TKT itu sendiri. Pertimbangan dalam deliberasi revisi undang-undang anti-terorisme di DPR-RI menunjukkan bahwa prioritas pembuktian suatu pelatihan para militer di luar negeri dengan aktivitas terorisme, yang menunjukkan masih diutamakannya mekanisme criminal justice ketimbang merespons kebahayaan TKT secara mutlak. Pemidanaan penyebarluasan informasi tentang pelatihan militer atau paramiliter yang diterima oleh seluruh anggota Pansus Revisi UU anti-teror DPR RI dapat memberikan mandat yang luas kepada penegak hukum untuk mendefinisikan mana informasi yang dapat mengarahkan pada pelatihan militer dan mana yang bukan. Sementara itu, tak diterimanya pencabutan paspor sebagai bagian dari perlakuan kepada para TKT tidak didominasi oleh pertimbangan kemanusiaan, tetapi lebih pada kekhawatiran bahwa proses hukum Indonesia tak dapat dilakukan dengan terjadinya pencabutan paspor. Secara keseluruhan, deliberasi DPR tentang pengaturan respons terhadap TKT masih didominasi oleh dukungan mereka kepada peran penegak hukum dan proses criminal justice dalam merespons terorisme.

Respons negara Indonesia terhadap problematika TKT sangat dibatasi oleh concern akan proses yang mengutamakan proses criminal-justice ketimbang mitigasi ancaman yang efektif dari kebahayaan teroris-kombatan. Perhatian lebih perlu diberikan kepada dua aspek penting yang belum didiskusikan dalam merespons TKT, yaitu penggentaran terhadap keberangkatan seseorang menjadi teroris-kombatan transnasional dan penguatan kapasitas reintegrasi dan rehabilitasi returnis teroriskombatan transnasional dan keluarganya.

\section{DAFTAR PUSTAKA}

Abuza, Zachary. "The Strategic and Tactical Implications of the Islamic State on Southeast Asia's Militant Groups." Georgetown Journal of Asian Affair, no. Fall (2016): 20-30.

Anindya, Chaula Rininta. "The Deradicalisation Programme for Indonesian Deportees: A Vacuum in Coordination." Journal for Deradicalization, no. 18 (2019): 217-43.

Argomaniz, Javier, Oldrich Bures, and Christian Kaunert. "A Decade of EU Counter-Terrorism and Intelligence: A Critical Assessment." Intelligence and National Security 30, no. 2-3 (2015): 191-206. 
Bakker, Edwin, and Roel de Bont. "Belgian and Dutch Jihadist Foreign Fighters (2012-2015): Characteristics, Motivations, and Roles in the War in Syria and Iraq." Small Wars and Insurgencies 27, no. 5 (2016): 837-57.

Benmelech, Efraim, and Esteban F. Klor. "What Explains the Flow of Foreign Fighters to ISIS?" Terrorism and Political Violence 00, no. 00 (2018): 1-24.

Bures, Oldrich. "EU's Response to Foreign Fighters: New Threat, Old Challenges?"

Terrorism and Political Violence 00, no. 00 (2018): 1-18.

Byman, Daniel. "How States Exploit Jihadist Foreign Fighters." Studies in Conflict and Terrorism 0, no. 0 (2017): 1-15.

"The Homecomings: What Happens When Arab Foreign Fighters in Iraq and Syria Return?" Studies in Conflict and Terrorism 38, no. 8 (2015): 581-602.

Carnegie, Paul J. "Is Militant Islamism a Busted Flush in Indonesia?" Journal of Terrorism Research 4, no. 2 (2013): $14-$ 25.

Commonwealth Secretariat. "CounterTerrorism: Measures to Fight against the Foreign Terrorist Fighter Phenomenon and the Use of ICT for the Recruitment of Terrorists." Commonwealth Law Bulletin 43, no. 3-4 (2017): 456-70.

Cragin, R. Kim, and Susan Stipanovich. "Metastases: Exploring the Impact of Foreign Fighters in Conflicts Abroad." Journal of Strategic Studies 42, no. 3-4 (2019): 395-424.

Crelinsten, R.D. "Analysing Terrorism and Counter-Terrorism : A Communication Model." Terrorism and Political Violence 14, no. 2 (2002): 77-122.
Dongen, T. W. van. "Break It down: An Alternative Approach to Measuring Effectiveness in Counterterrorism." Journal of Applied Security Research 6, no. 3 (2011): 357-71.

Eddyono, Supriyadi Widodo, and Ajeng Gandini Kamilah. "Sikap Fraksi DPR Dan Revisi UU Pemberantasan Tindak Pidana Terorisme: Memetakan Usulan Fraksi-Fraksi DPR Dalam Daftar Inventaris Masalah (DIM) RUU Pemberantasan Tindak Pidana Terorisme." Jakarta: ICJR, 2017.

Fitriani, Alif Satria, Pricilia Putri, Nirmala Sari, and Rebekha Adriana. "The Current State of Terrorism in Indonesia: Vulnerable Groups, Networks, and Responses." CSIS Working Paper Series, 2018, 19.

Islami, Nurfarahislinda M, Vidia Arianti, and Jennifer Yang Hui. "The Surprise Verdict: The Proscription of Jemaah Islamiyah." RSIS Commentary, no. 19 June (2008).

Johnson, Kirk A. "The Longue Duree: Indonesia's Response to the Threat of Jihadist Terrorism 1998-2016." Naval Postgraduate School, 2016.

K. Webb, Adam. "'Swanning Back in'? Foreign Fighters and the Long Arm of the State." CitizenshipStudies 21, no. 3 (2017): 291-308.

Kamilah, Ajeng Gandini, Siti Hardiyani, and Supriyadi Widodo Eddyono. "Pembahasan RUU Terorisme Di Panitia Khusus (Pansus) Komisi I DPR RI." Jakarta: ICJR, 2016.

Kementerian Hukum dan HAM. Peraturan Bersama Ketua Mahkamah Agung, Menteri Luar Negeri, Kepala Kepolisian Negara, Kepala Badan Nasional Penanggulangan Terorisme, DanKepala PusatPelaporanDan Analisis Transaksi Keuangan Nomor 01/PB/ MA/II/2015, 03, 1, B.66/K.BNPT/2/2015 Dan Nomor 0, Pub. L. No. 1/PB/MA/ II/2015，03， 1， B.66/K.BNPT/2/2015 \& 01/1.02/PPATK/2/2015 (2015). 
Malet, David, and Rachel Hayes. "Foreign Fighter Returnees: An Indefinite Threat?" Terrorism and Political Violence 00, no. 00 (2018): 1-19.

Marone, Francesco. "Ties That Bind: Dynamics of Group Radicalisation in Italy's Jihadists Headed for Syria and Iraq." International Spectator 52, no. 3 (2017): 48-63.

Milla, Mirra Noor, and Djamaludin Ancok. "The Impact of Leader-Follower Interactions on the Radicalization of Terrorists: A Case Study of the Bali Bombers." Asian Journal of Social Psychology 16, no. 2 (June 3, 2013): 92 100.

Nainggolan, Poltak Partogi. "Kekhalifahan ISIS Di Asia Tenggara, Sekedar Wacana Atau Realitas." Politica 8, no. 2 (2017): 205-30.

Rahmah, Unaesah. "Returning Indonesian IS Women and Children: What' s Next ?" Singapore: RSIS, 2019.

Ramakrishna, Kumar. "The Growth of ISIS Extremism in Southeast Asia: Its Ideological and Cognitive Features-and Possible Policy Responses." New England Journal of Public Policy 29, no. 1 (2017).

Republik Indonesia. Undang-Undang No. 5/2018 tentang Perubahan atas Undang-Undang No.15/2003 tentang Penetapan PERPU No.1/2002 Menjadi Undang-Undang (2018).
Solahudin \& Dave McRae. The Roots of Terrorism in Indonesia: From Darul Islam to Jema'ah Islamiyah. Sydney: NewSouth Publishing, 2011.

The Habibie Center. "Countering Vulnerability to Human Trafficking in Violent Extremism in Southeast Asia: A Case of Indonesia," 2018.

UNSC. "Resolution 2178 (2014) on Foreign Fighters" 2178, no. September (2014).

UNSC Counter-Terrorism Committee Executive DIrectorate (CTED). "The Challenge of Returning and Relocating Foreign Terrorist Fighters: Research Perspectives," n.d., 1-20.

Vaughn, Bruce, Emma Chanlett-Avery, Thomas Lum, Mark Manyin, and Larry Niksch. Terrorism in Southeast Asia. New York: Nova Science Publishers, 2008.

Wibisono, Ali Abdullah. "Fundamental Issues in Counterterrorism." The Jakarta Post. January 2016.

Wright, Christopher J. "Sometimes They Come Back: Responding to American Foreign Fighter Returnees and Other Elusive Threats." Behavioral Sciences of Terrorism and Political Aggression 0, no. 0 (2018): 1-16. 